\title{
Digital data and management accounting: why we need to rethink research methods
}

\author{
Alnoor Bhimani ${ }^{1}$ \\ Published online: 14 February 2020 \\ (c) The Author(s) 2020
}

\begin{abstract}
Digitalisation is having profound effects on how enterprises function. Its impact on accounting research is growing as the rise of the internet, mobile technologies and digital economy tools generate depth, breadth and variety of data that far exceed what researchers have had access to in the past. But whilst social scientists interested in organisational issues are starting to question conventional methodological approaches to the study of contexts where digital data forms are drawn upon, little such concern has been voiced in the management accounting literature. This paper seeks to explore the continued applicability of conventional methodological thinking when carrying out investigations within digital data environments to inform management accounting studies. It considers why digitalisation impacts methodological precepts, identifies how descriptive and explanatory modes of questioning which management accountants have conventionally opted for need rethinking, discusses ways in which digital data characteristics alter what can be drawn from empirical studies, and points to the potential offered within digitalised settings for methodological advance. It concludes by highlighting the necessity, where digitalisation exists, to question modes of posing questions and to reconsider the applicability of methodological precepts deployed by management accounting researchers to date.
\end{abstract}

Keywords Digitalisation · Methodology $\cdot$ Empiricism · Datafication

\section{Introduction}

Fifty years ago, the American Accounting Association defined accounting as: "The process of identifying, measuring and communicating economic information to permit informed judgements and decisions by users of the information" (AAA 1966, p. 1). Accounting scholars have since come to regard economic information as just a subset

\footnotetext{
$凶$ Alnoor Bhimani

a.bhimani@1se.ac.uk

1 London School of Economics, London, UK
} 
of information relevant to decision making. In relation to management accounting systems, there is widespread documentation that their design and modes of operation are influenced by social, institutional, and other organisational factors and that in different contexts, they deal with much more than just economic information or quantified metrics. Today, this is further changing. Digitalisation is having profound effects on how enterprises function particularly in the production and analysis of big data as part of control systems. The impact on accounting research is palpable as the rise of the internet, mobile technologies and digital economy tools generate depth, breadth and variety of data that far exceed what researchers have had access to in the past.

Social science researchers interested in organisational control dimensions are undertaking an increasingly broad set of investigations given the widened data sources in existence today (Hage 2018; Johns 2017). It is probably “....without question, social media data have changed the research landscape for social scientists." (Davis and Love 2019: 639). All the while, questions over the applicability of conventional methodological presumptions in these emerging research literatures are also being asked (Cade 2018; Miller and Skinner 2015; Yang and Liu 2017). Scholars with an interest in "datafication", that is the development of activities which can be traced digitally with extreme scale and accuracy and which is reshaping lives and experiences (Lycett 2013; Mayer-Schönberger and Cukier 2013), show more and more concern with how such investigations should be undertaken (Ausserhofer et al. 2017; Dourish and Gómez Cruz 2018; Van Es et al. 2018; Van Dijck 2014). Outside management-focused research, digitisation and datafication are seen to present important practical and theoretical research challenges and opportunities (Gattiglia 2017; O'Halloran et al. 2019; Qiu et al. 2018; Wesson and Cottier 2014). The need to be "aware of the limitations of any methodology" and to be "more analytical and less omnipotent" (Boullier 2018: 11) in the application of epistemological and ontological perspectives drawn from analogue world studies within digital data environments is being expressed.

Just as in the social sciences generally, accounting research has seen many advances in tools of investigation including the use of both quantitative and qualitative computerbased methods to help assess field notes and complex numerical relationships. But as Davis (2017: 2) notes “... innovations in qualitative and quantitative research are all, more or less, linear progressions. Big data is a move in a new direction. Big data isn't just about answering particular questions better, but about asking questions we didn't even know we had". Within the management accounting research literature, what we might seek to conceptualise, how we might do so and whether to question modes of posing questions themselves in the face of the rise of new digital data forms has not been the subject of much discussion. The intention of this paper is to expand the debate on whether management accounting researchers as social scientists now need to question the propriety of continuing to apply conventional methodological precepts in investigating digital data contexts.

The paper first considers how digitalisation impacts management accounting research. It then discusses descriptive versus explanatory research and approaches to methodological positioning. The third section of the paper addresses questions to be asked about digital data. Fourth, the paper looks at how digitalisation enhances research possibilities in management accounting after which some conclusions are drawn. 


\section{Why digitalisation affects accounting research}

New data contexts in which to examine research questions continually arise. Big data is a recent phenomenon that is deeply connected to what was an idea that has "...become the largest sociotechnical assemblage in human history in a little under 30 years" and which affects "... the lives, livelihoods and life chances of over half the world's population already, and connecting many more every day" (Staab et al. 2019: 74). It is now the case that we live in an era almost all human activity including organisational life can be recorded digitally (Alvarez 2016; Nagle 2017). The major mechanisms driving digitalisation today include digital technology innovations such as embedded internet of things devices, cloud computing, digitised supply chains and enterprise ecosystems and social media platforms among others (Blazquez and Domenech 2018; Hausberg et al. 2019). They give rise to data growth through management information systems processes and the proliferation of social networks, blogs, political discourse, company announcements, digital journalism, mobile messaging, home entertainment, online gaming, online financial services, online shopping, social advertising, and social commerce among others (Bhimani 2020; Chang et al. 2014). Digitalisation within firms has created very large quantities of data which are continuing to grow at an accelerating pace whilst also becoming more diverse in form making big data forever bigger, wider and more rapidly growing. Accounting academics have in this light recognised and highlighted the many accounting investigation possibilities where datafication prevails or is growing (Applebaum et al. 2017a; Cockcroft and Russell 2018; Gepp et al. 2018; Mancini et al. 2017; Moll and Yigitbasioglu 2019; Raffoni et al. 2018; Salijeni et al. 2019; Vasarhelyi et al. 2015; Warren et al. 2015).

There is little doubt that across enterprises and organisational platforms the rise of big data and their impact on management accounting controls and information as well as on decision making is reshaping the managerial reliance placed on more traditional information (Agarwal and Nijhawan 2016; Applebaum et al. 2017b; Bredmar 2017; Dagilienė and Klovienè 2019; Drew 2018). Big data and novel modes of analysis associated with the rise of digital technologies present organisational participants opportunities to utilise both structured and unstructured information for control purposes. Action based on such new information displays an important difference from the reliance on information systems output reflecting sequential and linear linkages that are part of pursued enterprise strategies and operations and attendant decision making that have guided the work of accountants in the past. There is now increased recognition that corporate strategy, organisational arrangements and information systems structures defy conventional ties traditionally seen to have connected them as greater appeal is made to big data based analyses and insights (Bhimani 2015; Krahel and Titera 2015). Moreover, costing architectures themselves have altered as links between data, information and knowledge have evolved (Al-Htaybat et al. 2017; Arnaboldi et al. 2017; Bhimani and Willcocks 2014; Căpușneanu et al. 2020; Richins et al. 2017; Rikhardsson and Yigitbasioglu 2018; Schneider et al. 2015; Troshani et al. 2019; Warren et al. 2015). Information outputs in organisations have transformed so much that few if any dimensions of business or management control processes today remain divorced from digital technology applications. Certainly, virtually all industrial 
sectors including manufacturing, transportation, health care, defence, energy, service and public sector activities are affected across economies (Vasarhelyi et al. 2015).

The rate at which organisations convert data insights into actions and the pliancy shown toward using heterogeneous data forms derived from diverse economic and social sources as well as the flexibility toward intermingling economic, operational, structured, unstructured, qualitative and numbers-based information has reached unparalleled heights. Enterprises today exercise data reach and plurality of information usages to inform enterprise action and guide operational processes of an order of magnitude never witnessed before in the history of organisational information systems usage. As such, accounting activities reliant only on pre-designed information inputs relating primarily to economic transactions with some coupling with non-financial information pools represents a fraction of control information deployment in digitalised enterprises. All dimensions of managerial action that can be influenced by datafication possibilities can be expected to open up novel control possibilities also.

The argument has been made that the vastness of new data forms does not elevate the rationality of decision making and indeed, that access to more digital data within enterprises "will make people take wrong decisions much more quickly than before" (Quattrone 2016: 120). What is clear is that scholarly studies in accounting will increasingly explore novel digital data forms, types and usages. As they do, accounting researchers will need also to reflect on the adequacy of the methodological approaches they adopt since their focus on widened data sources perforce embeds epistemological conditions that can alter the object of their investigations and place at risk their ability to develop tenable arguments. The next section identifies two forms of traditional accounting research concerns which have laid the premise for specific methodological presumptions which need to be reconsidered in investigating digitalised contexts.

\section{Asking 'what' and 'why' in management accounting research}

One view of information is that its use helps deal with the management of uncertainty (Jauch and Kraft 1986). Many management accounting activities in enterprises seek to produce information that lends greater clarity to managerial decision making and that enhances the perception of certainty of actions taken. In organisational environments where complexities grow, the general reaction of management accounting formality has been to re-structure information to enable its continued potential for uncertainty reduction and to aid management decision making. In instances where information structures have been challenged because of a perceived need to enhance organisational decision making clarity, the reaction has been to advance accounting techniques that adopt new formatting, novel structures or altered technical rationales. Managerial action and organisational transformations have reflected environmental changes such as for instance, growing production flexibility, product range increases and deeper and more rapid competitor shifts among others. Increased complexities between business objectives, operational processes and decision making has been responded to by novel management accounting approaches (such as activity based costing, target costing, balanced scorecards, standard costing systems etc.) which have become formalised management control measures in many enterprises. Management accounting changes 
have thus tended to encompass the adoption of standardised enterprise controls that reflect new information production and exchange needs. As organisational interconnections and risks have grown, new applications have been implemented to aid the management of uncertainty resulting in greater systemic homogeneity of management accounting approaches.

For management accounting scholars, such changes in accounting controls have presented many research opportunities. Some have engaged in descriptive investigations of management accounting techniques take-up by enterprises. Such investigations report on standard techniques usage identifying similarities and differences in adoption rates across firms, industrial sectors and geographies without necessarily seeking to explicate the basis for the reported differences. The descriptive management accounting practices literature has reported on numerous standard techniques in use in companies such as variable and full costing, choice of cost allocation bases, budgetary control practices, variance analysis and standard costing usage, pricing techniques, capital budgeting approaches, transfer pricing methods, activity-based costing applications, as well as balanced scorecards, life-cycle costing, and strategic accounting tools among others (Bhimani et al. 2019).

The concern with how techniques show differences and similarities across firms has been complemented by other scholarly studies that investigate why accounting outcomes are what they are. Explanatory research in management accounting attempts to identify causal factors and to offer rationales for the underlying reported differences. Most of these studies tend to posit deductive explanations based on other empirical studies previously undertaken in comparable contexts and/or drawing upon specific conceptual reference frames to demarcate propositions. To take an example, the contingency theory of management accounting has been regarded by some management accounting scholars as offering a theoretical frame for explaining the basis for similarities and difference in modes of organisational control implementations (Chapman 1997; Chenhall 2007; Gerdin and Greve 2004; Otley 2016). Some scholars posit an emic rather than an etic approach to contingency based management accounting research (Granlund and Lukka 2017) and others critique the determinism grounded in the contingency perspective (Fried 2017). Still, the generalist argument advanced within the contingency perspective has been built on the premise that control systems deployment in enterprises is linked to the existence of supra-national forces of change whereby firms become more alike as economies converge over time (Donaldson 1995; Hickson et al. 1974). So differences become suppressed as homogenising factors inform the architecture of controls within firms (Mueller 1994). Scholars who adopt a contingency argument to explain similarities and difference have identified broad environmental factors such as for instance the manner in which managerial hierarchies are structured vis-as-vis the stage within a notional trajectory of industrialisation which an economy finds itself in. Under this perspective, economic transformation drives market, technical, and organisational dependencies which compel firms to arrange their internal structures by reference to a set of functional control possibilities (Otley 2016).

Another stance adopted by some scholars is the "political economy" perspective which focuses on contradictions within capitalism that mobilise broadly similar trends in the management and structuring of the labour process. Profit seeking organisations 
are viewed to exhibit similarities in managerial controls to oversee the conduct of work and the standardisation of tasks (Armstrong 1987; Cooper and Hopper 1990; Roslender 1996; Thompson and Smith 2010). The notion that imperatives (either contingency or labour-process based) prevail across social, economic, or political systems and that mould organisational controls within a trajectory of progression enables explanations as to specific functioning modes implemented by organisations and the formal controls they ultimately operationalise. The argument advanced within this conceptual perspective rests on the contention that structural changes over time follow a specific path of evolution and that organisations in the settings under study manifest corresponding likeness.

The premise within both contingency and political economy perspectives is that organisational contexts follow a trajectory that overarches the particularity of enterprise characteristics. As such, advances accord organisations likeness of control approaches that echo the homogenising effects of industrial change. Converging influences manifest whereby technological, market, strategic, labour and other contextual variables exhibit replicating interdependencies in relation to organisational structuring which underpin control changes. Such scholarly explanations as to organisational control operationalisations rest on argumentation that presumes the stability of relationships between environmental characteristics and organisational features and processes including management accounting approaches.

Management accounting research resting on notions of converging influences tied to presumptions of industrial evolution are, within digitalised settings, in need of qualitative re-assessment. The stability of relationships cannot be assumed of emerging business models in the fast transforming digital economy (Wadan et al. 2019). The time is also now to questions the applicability of quantitative approaches that have been deployed in studying analogue organisational settings whose information systems are linearly arranged and to ponder their continued appropriateness given the altered process structures of digitalised enterprise contexts. The issue goes beyond the paradigmatic legitimacy of using quantitative research norms drawn from the pure sciences to qualitative investigations (Aguinis et al. 2017; Denzin 2010; Pratt et al. 2019).

As scholars pose research questions, opting for either descriptive or explanatory routes in relation to the study of digitalised enterprise controls, they need to also ponder whether the data from such can be subsumed within traditional methodological conceptions of data inquiry. It may be that the transition from analogue to digital has ushered in different parameters of evolutionary enterprise control structuring which need to be explored. By the same token, it is difficult to contest that digital technologies associated with the production of big data can lead to inferences that "covertly or overtly, consciously or inadvertently" (Robertson and Travaglia 2018: 2) support specific ideologies. In other words, both quantitative and qualitative methodologies deployed within established management accounting research efforts embed epistemological, ontological and ideological preconceptions that need elaboration. Possibly, “... the change from a largely analogue small data environment to a foundationally digital one has not undermined the pervasive ideologies that the small data paradigm produced and institutionalised" (Ibid.). It becomes therefore essential for management accounting researchers to ponder what conceptions of research become imported into 
new realms of analyses that rest on vastly different data forms and sources and whether what is interpreted about the new data is aided or obfuscated by past norms of research propriety. The paper turns now to discussing data specific implications of management accounting research focussing on digital contexts.

\section{Questions about data that can change the questions we pose}

Accounting scholars will continue to explore accounting structures and what underpins their functioning. The underlying forces that tie contextual factors to accounting however are changing and a need exists to reflect on how appropriate it is to adopt conventional research precepts in exploring accounting issues within digitalising environments. A number of issues associated with the nature of data resulting from digitalisation suggest that such reflection has become essential. First, a marked change is in evidence whereby the presumed connections between action and control systems input and their consequences in conventional accounting usage settings have altered. The evolution of digital technologies has upended the sequential linearity which has traditionally directed organisational activities. The pursuit of specific defined organisational strategies can, in some instances, give rise to particular management controls but that logic cannot be assumed to reside in digitalised enterprises. The notion that sequential and traceable paths of effects are present where in fact new inter-dependencies associated with digitalised platform based organisational control models and altered data creation and exchanges are in play no longer hold (Willcocks et al. 2014). Contingency reasoning resting on the idea that enterprise strategies sponsor technological responses which yield specific accounting control outcomes has to be questioned since the sequential agency baked into conventional control mechanisms is seemingly absent in digitalised settings (Bhimani and Willcocks 2014). Information relevance and the linear sequencing of control information and action drawn upon for information analysis by decision makers is not an essential part of digitalised enterprise activity. Consequently, it is essential to acknowledge that ways in which accounting controls in digitalised organisations differ from traditional settings as data forms and flows have altered. This needs to be reflected in revising the research questions we ask.

Second, datafication has altered the premise on which management accounting justifies its raison d'être. Whilst the objective to provide financial and non-financial decision-making information to managers may seem laudable as management accounting's primary pursuit, this prescriptive view confines the field to the application of solutions and a focus on data that are no longer hold primacy in many digitalised enterprises. Aside from formal financial data and operational records of processes or economic transactions, digitalised enterprises produce "exhaust data" or "trace data" which are part of the digital records of activities and events that engage information technologies such as data from clickstreams, sensor data, and social media updates. Such data bypasses capture by traditional accounting information systems since they lack any direct link to verifiable economic impact. However, digitalised organisational platforms produce at least some elements of trace as part of log files, documents or communication trails which culminate in data perceived to be of relevance to controls 
and viewed as a desirable source of business intelligence. Appeal to such additional forms of data, structured and unstructured, have implications for researchers. Different investigatory questions may be posed and studies may benefit from redefinition of scale and scope in the light of more diverse data types. Digitised data may for instance be seen to lag or lead the direction captured by formal data and operational information. They may signify reinforcement or upending of articulated organisational pursuits. Such data, given their abundance and speed of production, may lead researchers to redefine the depth and time focus of their investigations.

Third, digitalised enterprises may exhibit pathways to organisational changes that do not accord with established management theories. This then could confound inference-focused methodologies adopted by accounting scholars. It may be that research methods could be widened drawing from the data sciences (George et al. 2016). To take an example, suppose that enterprises reveal that engagement in big data analysis leads to the identification of patterns giving rise to new organisational strategies. This then opens up room for questioning the premise upon which strategic management theorising rests in relation to strategy formulation and formation (Furrer and Goussevskaia 2008; Langfield-Smith 1997, 2006; Sminia 2009) and the conventional predictions that can be derived from the prior literature (Grattan 2016). If it is apparent that new enterprise visibilities based on research data collected can lead to altered strategies that overarch any reference to traditional conceptions of strategic engagement, then one must interrogate whether prior studies supporting linkages between strategy and accounting and the methods adopted therein can reasonably guide research endeavours that rely on data which defy traditionally perceived patterns of flow.

Fourth, research in digitalised organisations, can reveal useful data sources that are 'found' rather than produced by design. These can aid enterprise decision making but in contrast to formalised systems derived information that have purposefully 'generated' data with specific intents, their provenance is circumstantial. Moreover, trace data are different from many other common forms of social science data in that they are usually "event-based" records of activities and transactions. Additionally, trace data are ordinarily longitudinal and time-stamped sequences of activities. Further still, they may not be cross-sectional and thereby serve a number of alternative and possibly novel research purposes. Recognition that digital data can be a by-product of activities instead of data generated for the purpose of either organisational control or indeed for the research enterprise is important to acknowledge. Importantly, the specific characteristics and properties of digitalisation derived data makes for potentially extremely significant advances in academic research. This is further discussed in the next section.

\section{Can digitalisation widen the research potential?}

Scholarly claims must align with norms of legitimacy in accounting research. Deviating from these can derail investigations if established research robustness preconditions are sidestepped (Creswell 2003; Frade 2016; McFarland and McFarland 2015). But there must also be recognition that approaches to data, method and theoris- 
ing can be altered and expanded as researchers engage with novel bases of empiricism. Investigations using data from digitalised organisations, whether financial, structured and formally produced or non-financial, unstructured and trace-derived, have the potential to make insightful claims about the technical, organisational and social characteristics of accounting. Digitalisation therefore offers immense opportunities in this respect but requires safeguards to maintain traditionally desirable parameters of research integrity. This has to be balanced with the potential of conceptualisations from research that could not be had by too closely remaining wedded to past ideologies of research integrity. To take an example, within explanatory management accounting research, the tendency has been to demarcate between deductive versus inductive research. Digital data forms enable emancipatory departures from this research divide than before.

The availability of trace data can enable inductively generated novel theorising to emerge. Still, as with the edicts of conventional research legitimacy, one cannot overreach in yielding conclusions from empirics when the data source does not permit. It is important therefore to be mindful that trace data tend not to be generalisable outside of the platforms from which the data originate. This is particularly so when trace data links into social media bases. Participation on digitalised platforms that generate such data is not usually universally representative of the wider population that interacts with an organisation or industrial sector within the object of study. These data sets may also be demographically biased. Access to data or to platforms that create such data may further be infra-structurally constrained. Organisationally linked media data are partial, demographically skewed, and not always consistently available. Consequently, empirical generalisability may not be attainable and theoretical generalisability must not be inappropriately posited. As Davis and Love (2019: 637) warn, researchers must bear in mind that: "Through a mask of objectivity, claims about 'social life' derived from social media data present the partial and the skewed as general and universal".

Trace data assessment can buttress conventional hypothetic-deductive methods but also can lead scholars to build and elaborate theory by subjecting the data to extensive analysis. Importantly, the availability of different data forms that have not been available to researchers before offer the possibility to inductively engage such data within a grounded theoretical frame (Charmaz 2014; Glaser and Strauss 1967) rather than to pursue hypotheses propositions and testing aligned with deductive methodological convention. Grounded theory that seeks to develop theoretical concepts and relationships can become viable where digitalised data forms, because of their scale and variety and the data characteristics noted above, offer prospects for delving beyond deduction.

Big data analytics using focused computational methods that prioritise speculative data mining to highlight pattern recognition and unexpected correlations can inform the accounting research domain (Appelbaum et al. 2017a, b; Geppa et al. 2018; Schneider et al. 2015). Pitfalls nevertheless exist in that simple mining for insights overlooks questions that could be more theoretically informed and to some, the value of such investigations "remains very much open to question" (Goldthorpe 2016:81). The importance of and the possibilities open to qualitative researchers to "... conduct 'big qual' analysis while retaining the distinctive order of knowledge about social processes" remains (Davidson et al. 2019: 264). There certainly can be continuity in 
data enabled by the combination of qualitative and quantitative methods in the digital world (Venturini et al. 2017). Indeed, Halford and Savage (2017: 1133) suggest that researchers might take a 'symphonic' approach to big data analysis where "recurring descriptive motifs woven together within a complex temporal narrative" are made visible. They advocate a perspective that combines rich theoretical awareness with data that can address wide questions rather than simply mobilising the ad hoc mining of large data sets in search of inductive patterns where "hermeneutic and critical analysis" are displaced. A precaution is for the data set assessed not to be short period collections of say purchasing patterns and production activities over limited time and context spans but wider ranges of points over extended time frames. The intent should not be to have the data infer associations based purely on detected correlations but to use concepts and theorising that connect to recurring motifs such that there emerges a broader narrative. Certainly, studies must not abandon traditionally important considerations of social science research including data representativeness and sampling biases and it is important that conclusions that relate to a whole population are not based on results gathered from partial analyses reliant on narrow data sets (Hargittai 2018; Lazer et al. 2009, 2014). The preferred approach should then be to intertwine sound theoretical understanding with wide ranging data that reveal recurring motifs.

Methodologically, some steps that are long established in social science research are important to adhere to. Halford et al. (2018) advance the need for high transparency as to the data being used. In other words, extreme diligence is required in reporting the way in which data are harvested. This could mean keeping tabs and records of principal metrics that relate to the data set or streams. The possibility of transparency must therefore remain. It is likewise important to understand the limits of the data in terms of what it could reveal and what not. Moreover, the construction of data is important to explain as researchers often organise the data to be analysed to enable a particular questioning slant to be operationalised such as for instance, deliberately biasing the population set to evince more information about an under-represented management control characteristic. This avoids making inferences that supersede the specificity of the data set. The questions to be asked should, in other words, guide the approach and the claims should align with the data selected for analysis.

Whilst methodological fundamentals typical of empirical analyses using data sets for investigation of traditional or big data contexts may have parallels, the availability of digitalised data affords more flexibility to deviate from common research points of departure. In effect, rather than make distinct the starting point of a research endeavour in relation to engaging in deductive or inductive reasoning, what may be sought is abductive reasoning from the outset where tools and data are engaged in within a critical process of interrogation which may change during the investigatory stage. Certainly, "...emic-level empirical analysis at the core of interpretive research is connected to etic-level analysis and knowledge" (Lukka (2014: 561), but in relation to digitalised enterprise contexts, primacy can be given to the "unfolding interplay between data, method and theory and with regard to their co-constitution" (Halford and Savage 2017: 1143). 


\section{Summary}

Some scholars have argued that digital data has done "nothing less than to revolutionise the social sciences" and is "challenging established paradigms" (Berente et al. 2018:2). Accounting research is not exempt. The case for re-thinking how legitimate it is to apply conventional methodological precepts in investigating digital data contexts to inform management accounting studies cannot be made too strongly. The paper has discussed digitalisation as having led to massive data growth both from non-formal structures as well as from management information systems producing and processing economic and new forms of data that are structured and unstructured. The impact of digitalisation on management accounting research is growing as we gain access to greater depth, breadth and variety of data. This is creating an investigatory landscape offering exponentially growing qualitative and quantitative research domains. The focus on digitalised data raises issues of method for accounting research given that organisational information platforms now encompass the analysis of data not conventionally part of management control research. Digital data characteristics embed features that can challenge established paradigms about data and lead to altered ontological notions of the informational nature of data. The growth of analysable data, structured and unstructured, as well as formally intended and circumstantial, alters the premise upon which researchers can design their investigative work and the methodological precepts they adopt or indeed, devise.

It might be said that digitalisation within enterprises offers researchers an epochal opportunity to investigate what has not been possible in the history of management accounting investigations. This is because digital data are "more evenly distributed across the span of collective existence of which they therefore offer a more continuous appraisal" (Rogers 2013: 4). Management scholars have pointed to the handling of big data and how analytical tools provided by data science can be adapted and altered to not only seek better answers to existing questions but also for posing new questions (George et al. 2016; Kuo and Kusiak 2019; Mikalef et al. 2018; Spanaki et al. 2018; Tonidandel et al. 2018). What may be derived from research using larger volumes of data that emerges faster than ever before and which is more varied in structure whilst also offering specific characteristics such as time-stamping and chronology, goes beyond what has been empirically available to us. Features that characterise digital data alter the potential of investigations in relation to the limits and possibilities of digital empiricism. Along with an unprecedented array of new data, digitalisation has brought with it novel options for how to and what to research, as well as a need to re-assess our conventional conceptions of methods legitimacy and ultimately, what we regard as having scholarly rigour.

Open Access This article is licensed under a Creative Commons Attribution 4.0 International License, which permits use, sharing, adaptation, distribution and reproduction in any medium or format, as long as you give appropriate credit to the original author(s) and the source, provide a link to the Creative Commons licence, and indicate if changes were made. The images or other third party material in this article are included in the article's Creative Commons licence, unless indicated otherwise in a credit line to the material. If material is not included in the article's Creative Commons licence and your intended use is not permitted by statutory regulation or exceeds the permitted use, you will need to obtain permission directly from the copyright holder. To view a copy of this licence, visit http://creativecommons.org/licenses/by/4.0/. 


\section{References}

Agarwal, R., \& Nijhawan, S. (2016). Big data and continuous monitoring: A synergy whose time has come? Internal Auditing, 31(1), 19-26.

Aguinis, H., Cascio, W. F., \& Ramani, R. S. (2017). Science's reproducibility and replicability crisis: International business is not immune. Journal of International Business Studies, 48, 653-663.

Al-Htaybat, K., \& Alberti-Alhtaybat, L. (2017). Big data and corporate reporting: impacts and paradoxes. Accounting, Auditing and Accountability Journal, 30(4), 850-873.

Alvarez, M. (2016). Computational social science: Discovery and prediction. Cambridge: Cambridge University Press.

Appelbaum, D., Kogan, A., \& Vasarhelyi, M. (2017a). Big data and analytics in the modern audit engagement: Research needs. Auditing: A Journal of Practice and Theory, 36(4), 1-27.

Appelbaum, D., Kogan, A., Vasarhelyi, M., \& Yan, Z. (2017b). Impact of business analytics and enterprise systems on managerial accounting. International Journal of Accounting Information Systems, 25, 29-44.

Armstrong, P. (1987). The rise of accounting controls in British capitalist enterprises. Accounting, Organizations and Society, 12(5), 436-445.

Arnaboldi, M., Busco, C., \& Cuganesan, S. (2017). Accounting, accountability, social media and big data: Revolution or hype? Accounting, Auditing and Accountability Journal, 30(4), 762-776.

Ausserhofer, J., Gutounig, R., Oppermann, M., Matiasek, S., \& Goldgruber, E. (2017). The datafication of data journalism scholarship: Focal points, methods, and research propositions for the investigation of data-intensive newswork. Journalism. https://doi.org/10.1177/1464884917700667.

Berente, N., Seidel, S., \& Safadi, H. (2018). Research commentary: Data-driven computationally intensive theory development. Information Systems Research. https://doi.org/10.1287/isre.2018.0774.

Bhimani, A. (2015). Exploring big data's strategic consequences. Journal of Information Technology, 30(1), 66-69.

Bhimani, A. (2020). Accounting disrupted: The reshaping of financial intelligence in the new digital era. New York: Wiley.

Bhimani, A., Horngren, C. T., Datar, S. M., \& Rajan, M. (2019). Management and cost accounting. London: Pearson.

Bhimani, A., \& Willcocks, L. (2014). Digitisation, 'big data' and the transformation of accounting information. Accounting and Business Research, 44(4), 469-490.

Blazquez, D., \& Domenech, J. (2018). Big data sources and methods for social and economic analyses. Technological Forecasting and Social Change, 30, 99-113.

Boullier, D. (2018). Medialab stories: How to align actor network theory and digital methods. Big Data and Society July-December, 5(2), 1-13.

Bredmar, K. (2017). Digitalisation of enterprises brings new opportunities to traditional management control. Business Systems Research, 8(2), 115-125.

Cade, N. L. (2018). Corporate social media: How two-way disclosure channels influence investors. Accounting, Organizations and Society, 68(1), 63-79.

Căpușneanu, S., Topor, D., Constantin, D., \& Marin-Pantelescu, A. (2020). Management accounting in the digital economy. In I. Oncioiu (Ed.), Improving business performance through innovation in the digital economy (pp. 156-176). Romania: IGI Publishing.

Chang, R. M., Kauffman, R. J., \& Kwon, Y. (2014). Understanding the paradigm shift to computational social science in the presence of big data. Decision Support Systems, 63(1), 67-80.

Chapman, C. S. (1997). Reflections on a contingency view of accounting. Accounting, Organizations and Society, 47(1), 189-205.

Charmaz, K. (2014). Constructing grounded theory. London: Sage.

Chenhall, R. H. (2007). Theorising contingencies in management accounting research. In C. Chapman, A. Hopwood, \& M. Shields (Eds.), Handbook of management accounting research (pp. 163-206). Oxford: Elsevier.

Cockcroft, S., \& Russell, M. (2018). Big data opportunities for accounting and finance practice and research. Australian Accounting Review, 28(3), 323-333.

Cooper, D., \& Hopper, T. (1990). Critical accounts: Reorienting accounting research. London: MacMillan Press.

Creswell, J. W. (2003). Research design: Qualitative, quantitative, and mixed method approaches. Thousand Oaks: Sage. 
Dagilienè, L., \& Klovienè, L. (2019). Motivation to use big data and big data analytics in external auditing. Managerial Auditing Journal, 34(7), 750-782.

Davidson, E., Edwards, R., Jamieson, L., \& Weller, S. (2019). Big data, qualitative style: A breadth-anddepth method for working with large amounts of secondary qualitative data. Quality and Quantity, 53(1), 363-376.

Davis J. L. (2017). Big data and the epistemological renaissance. https://thesocietypages.org/cyborgology/ 2017/06/05/big-data-and-the-epistemological-renaissance/.

Davis, J. L., \& Love, T. P. (2019). Generalizing from social media data: A formal theory approach. Information, Communication and Society, 22(5), 637-647.

Denzin, N. (2010). Moments, mixed methods and paradigm dialogs. Qualitative Inquiry, 16(6), $419-427$.

Donaldson, L. (1995). American anti-management theories of organizations. Cambridge: Cambridge University Press.

Dourish, P., \& Gómez Cruz, E. (2018). Datafication and data fiction: Narrating data and narrating with data. Big Data and Society, December, 1-10.

Drew, J. (2018). Merging accounting with 'big data' science. Journal of Accountancy., 226(1), 48-52.

Frade, C. (2016). Social theory and the politics of big data and method. Sociology, 50(5), 863-877.

Fried, A. (2017). Terminological distinctions of 'control': A review of the implications for management control research in the context of innovation. Journal of Management Control, 28(1), 5-40.

Furrer, O., \& Goussevskaia, A. (2008). The structure and evolution of the strategic management field: A content analysis of 26 years of strategic management research. International Journal of Management Reviews, 10(1), 1-23.

Gattiglia, G. (2017). From digitization to datafication: A new challenge is approaching archaeology. In AIUCD 2017 conference "The educational impact of DSE”, 23-28 January 2017, Rome (proceedings).

George, G., Osinga, E., Lavie, D., \& Scott, B. (2016). Big data and data science methods for management research: From the editors. Academy of Management Journal, 59(5), 1493-1507.

Gepp, A., Linnenlueckeb, M., O’Neilla, T., \& Smith, T. (2018). Big data techniques in auditing research and practice: Current trends and future opportunities. Journal of Accounting Literature, 40, 102-115.

Gerdin, J., \& Greve, J. (2004). Forms of contingency fit in management accounting research: A critical review (pp. 303-326). Accounting: Organizations and Society.

Glaser, B. G., \& Strauss, A. L. (1967). The discovery of grounded theory: Strategies for qualitative research. Chicago: Aldine Publishing Company.

Goldthorpe, J. (2016). Sociology as a population science. Cambridge: Cambridge University Press.

Granlund, M., \& Lukka, K. (2017). Investigating highly established research paradigms: Reviving contextuality in contingency theory based management accounting research. Critical Perspectives on Accounting, 45, 63-80.

Grattan, R. (2016). Strategic Review: The process of strategy formulation in complex organizations. Oxon: Routledge.

Hage, J. (2018). Organizational innovation. Oxon: Routledge.

Halford, S., \& Savage, M. (2017). Speaking sociologically with big data: symphonic social science and the future for big data research. Sociology, 51(6), 1132-1148. https://doi.org/10.1177/ 0038038517698639.

Halford, S., Weal, M., Tinati, R., Carr, L., \& Pope, C. (2018). Understanding the production and circulation of social media data: Towards methodological principles and praxis. New Media and Society, 20(9), $3341-3358$.

Hargittai, E. (2018). Potential biases in big data: omitted voices on social media. Social Science Computer Review, 7(1), 1-15.

Hausberg, J. P., Liere-Netheler, K., Packmohr, S., Pakura, S., \& Vogelsang, K. (2019). Research streams on digital transformation from a holistic business perspective: A systematic literature review and citation network analysis. Journal of Business Economics, 89, 931-963.

Hickson, D. J., Hinnings, C. R., McMillan, C. J., \& Schwitter, J. P. (1974). The culture-free context of organizational structure: A tri-national comparison. Sociology, 8(2), 59-80.

Jauch, L., \& Kraft, K. (1986). Strategic management of uncertainty. Academy of Management Review, 11(4), $133-143$.

Johns, G. (2006). The essential impact of context on organizational behavior. Academy of Management Review, 31(2), 386-408.

Johns, G. (2017). Incorporating context in organizational research. Academy of Management Review, 42(4), $383-402$. 
Krahel, J. P., \& Titera, W. R. (2015). Consequences of Big data and formalization on accounting and auditing standards. Accounting Horizons, 29(2), 409-422.

Kuo, Y., \& Kusiak, A. (2019). From data to big data in production research: the past and future trends. International Journal of Production Research, 57(1), 4828-4853.

Langfield-Smith, K. (1997). Management control systems and strategy: A critical review. Accounting, Organizations and Society, 22(2), 207-232.

Langfield-Smith, K. (2006). A review of quantitative research in management control systems and strategy. Handbooks of Management Accounting Research, 2, 753-783.

Lazer, D., Kennedy, R., \& King, G. (2014). The parable of Google Flu Trends: Traps in big data analysis. Science, 343(6), 1203-1205.

Lazer, D., Pentland, A., Adamic, L., Aral, S., Barabasi, A., Brewer, D., et al. (2009). Life in the network: The coming age of computational social science. Science, 323(5915), 721-723.

Lukka, K. (2014). Exploring the possibilities for causal explanation in interpretive research. Accounting, Organizations and Society, 39(7), 559-566.

Lycett, M. (2013). 'Datafication': Making sense of (big) data in a complex world. European Journal of Information Systems, 22(4), 381-386.

Mancini, D., Lamboglia, R., Castellano, N. G., \& Corsi, K. (2017). Trends of digital innovation applied to accounting information and management control systems. In K. Corsi, N. Castellano, R. Lamboglia, \& D. Mancini (Eds.), Reshaping accounting and management control systems. Berlin: Springer.

Mayer-Schönberger, V., \& Cukier, K. (2013). Big data: A revolution that will transform how we live, work and think. London: John Murray.

McFarland, D., \& McFarland, H. (2015). Big data and the danger of being precisely inaccurate. Big Data and Society, July-December, 1-4.

Mikalef, P., Pappas, I. O., \& Krogstie, J. (2018). Big data analytics capabilities: A systematic literature review and research agenda. Information Systems and e-Business Management, 16, 547-578.

Miller, G. S., \& Skinner, D. J. (2015). The evolving disclosure landscape: How changes in technology, the media, and capital markets are affecting disclosure. Journal of Accounting Research, 53(2), 221-239.

Moll, J., \& Yigitbasioglu, O. (2019). The role of internet-related technologies in shaping the work of accountants: New directions for accounting research. The British Accounting Review, 51(6), 1-20.

Mueller, F. (1994). Societal effect, organizational effect and globalization. Organization Studies, 15(3), $407-428$.

Nagle, T. (2017). Technology, the future and us. In M. Quinn \& E. Strauss (Eds.), The Routledge companion to accounting information systems (pp. 262-271). Abingdon: Routledge.

O'Halloran, K., Tan, S., Wignell, P., Bateman, J., Pham, D., Grossman, M., et al. (2019). Interpreting text and image relations in violent extremist discourse: A mixed methods approach for big data analytics. Terrorism and Political Violence, 31(3), 454-474.

Otley, D. (2016). The contingency theory of management accounting and control: 1980-2014. Management Accounting Research, 31(2), 45-62.

Pratt, M. G., Kaplan, S., \& Whittington, R. (2019). Editorial essay: The tumult over transparency-Decoupling transparency from replication in establishing trustworthy qualitative research. Administrative Science Quarterly. https://doi.org/10.1177/0001839219887663.

Qiu, L., Chan, S. H. M., \& Chan, D. (2018). Big data in social and psychological science: Theoretical and methodological issues. Journal of Computational Social Science, 1, 59-66.

Quattrone, P. (2016). Management accounting goes digital: Will the move make it wiser? Management Accounting Research, 31(2), 118-122.

Raffoni, A., Visani, F., Bartolini, M., \& Silvi, R. (2018). Business performance analytics: Exploring the potential for performance management systems. Production Planning and Control, 29(1), 51-67.

Richins, G., Stapleton, A., Stratopoulos, T., \& Wong, C. (2017). Big data analytics: Opportunity or threat for the accounting profession? Journal of Information Systems, 31(3), 63-79.

Rikhardsson, P., \& Yigitbasioglu, O. (2018). Business intelligence and analytics in management accounting research: Status and future focus. International Journal of Accounting Information Systems, 24, 37-58.

Robertson, H., \& Travaglia, J. (2018). An emerging iron cage? Understanding the risks of increased use of big data applications in social policy. Impact of Social Sciences Blog, 10, 3415.

Rogers, R. (2013). Digital methods. Cambridge: MIT Press.

Roslender, R. (1996). Critical accounting and the labour of accountants. Critical Perspectives on Accounting, 7(4), 461-484. 
Salijeni, G., Samsonova-Taddei, A., \& Turley, S. (2019). Big data and changes in audit technology: Contemplating a research agenda. Accounting and Business Research, 49(1), 95-119.

Schneider, G., Dai, J., Janvrin, D., Ajayi, K., \& Raschke, R. (2015). Infer, predict, and assure: Accounting opportunities in data analytics. Accounting Horizons, 29(3), 719-742.

Sminia, H. (2009). Process research in strategy formation: Theory, methodology and relevance. International Journal of Management Reviews, 11(1), 97-125.

Spanaki, K., Gürgüç, Z., Adams, R., \& Mulligan, C. (2018). Data supply chain (DSC): Research synthesis and future directions. International Journal of Production Research, 56(13), 4447-4466.

Staab, S., Halford, S., \& Hall, W. (2019). Web science in Europe. Communications of the ACM, 62(4), 74-82.

Thompson, P., \& Smith, C. (2010). Working life: Renewing labour process analysis. NY: Palgrave McMillan.

Tonidandel, S., King, E., \& Cortina, J. (2018). Data methods: Leveraging modern data analytic techniques to build organizational science. Organizational Research Methods, 21(3), 525-547.

Troshani, I., Locke, J., \& Rowbottom, N. (2019). Transformation of accounting through digital standardisation: Tracing the construction of the IFRS taxonomy. Accounting, Auditing and Accountability Journal, 32(1), 133-162.

Van Dijck, J. (2014). Datafication, dataism and dataveillance: Big data between scientific paradigm and ideology. Big Data Surveillance, 12(2), 197-208.

Van Es, K, Wieringa, M. \& Schäfer, M. T. (2018). ToolCriticism: From digital methods to digital methodology. In InInternational Conference on Web Studies (WS.2 2018), October 3-5, 2018, Paris, France. ACM, New York, NY, USA. https://doi.org/10.1145/3240431.3240436.

Vasarhelyi, M., Kogan, A., \& Tuttle, B. (2015). Big data in accounting: An overview. Accounting Horizons, 29(2), 381-396.

Venturini, T., Jacomy, M., \& Meunier, A. (2017). An unexpected journey: A few lessons from Sciences Po Médialab's experience. Big Data and Society, 4(2), 1-11.

Wadan, R., Teuteberg, F., Bensberg, F., \& Buscher, G. (2019). Understanding the changing role of the management accountant in the age of industry 4.0 in Germany. In Proceedings of the 52nd Hawaii international conference on system sciences. https://hdl.handle.net/10125/60017.

Warren, J., Moffitt, K., \& Byrnes, P. (2015). How big data will change accounting. Accounting Horizons, 29(2), 397-407.

Wesson, C. B., \& Cottier, J. W. (2014). Big sites, big questions, big data, big problems: Scales of investigation and changing perceptions of archaeological practice. Bulletin of the History of Archaeology, 24(16), $1-11$.

Willcocks, L., Venters, W., \& Whitley, E. (2014). Moving to the cloud corporation: How to face the challenges and harness the potential of cloud computing. London: Palgrave.

Yang, J. H., \& Liu, S. (2017). Accounting narratives and impression management on social media. Accounting and Business Research, 47(6), 673-694.

Publisher's Note Springer Nature remains neutral with regard to jurisdictional claims in published maps and institutional affiliations. 